\title{
The future of ruins: the baroque melancholy of Hashima
}

\section{Carl Lavery}

Theatre, Film and Television, College of Arts, University of Glasgow, Gilmorehill Halls, 9 University Avenue, Glasgow G12 8QQ, Scotland; e-mail: carl.lavery@glasgow.ac.uk

\section{Deborah P Dixon 1}

School of Geographical and Earth Sciences, University of Glasgow, East Quadrangle, University Avenue, Glasgow G12 8QQ, Scotland; e-mail: Deborah.dixon@glasgow.ac.uk

\section{Lee Hassall}

Fine Art, Art and Science Building, University of Lincoln, Brayford Pool, Lincoln LN6 7TS, England; e-mail: 1hassall@lincoln.ac.uk

Received 2 April 2013; in revised form 7 July 2014; published online 16 October 2014

\begin{abstract}
Here, we present an iteration of our theoretical/creative writing project Hashima, begun in 2012. The paper is a collaboration and draws on the different discourses, practices and sensibilities of a performance theorist, a geographer, and a visual artist. For us, Hashima, located off the coast of Nagasaki, Japan, and a former site of forced labor and intensive offshore coal-mining, is a provocation for experimentation. Hashima, exploited and abject, has offered itself, unsurprisingly, to the fetishistic gaze of artists, photographers urban explorers, and ruin enthusiasts. The logic here is to control representation, and to determine and fix the meaning of the island as always in reference to something else and elsewhere. Paradoxically, there is no sense of temporality or transformation in these representations of ruins; time has been stopped in an image. By contrast, we want to draw out the allegorical value of Hashima not as a site of loss, but as a baroque, blasted landscape of monstrous becomings that resists, and forefronts, this tendency to collapse history into nature. In the following, we introduce the island before turning to an exegesis of Walter Benjamin's writing on German baroque tragedy in order to demonstrate how representation itself becomes tainted through a material encounter with the baroque's two primary topoi, the ruin and the labyrinth. To do this, we finish with a creative narrative and two images illustrating our methodology.
\end{abstract}

Keywords: allegory, ruins, history, creative writing, experiment

"Allegories are in the realm of thoughts, what ruins are in the realm of things."

Walter Benjamin (2003, page 178)

\section{Introducing Hashima}

Hashima Island is situated in the East China Sea, roughly 18 or so kilometers from Nagasaki City and, prior to settlement, was a reef extending around 125 by 300 meters. The smallscale mining of exposed coal beds had been a feature of neighboring island economies for centuries, but increased demand for coal for the Japanese salt-making industry, and emerging fleets of steam-powered ships, in combination with the introduction of mining equipment from Britain, initiated a major drilling project on Takashima Island in 1869, and its neighbor Hashima Island in 1887. Three years later Hashima was sold to the Mitsubishi company, a fast-growing shipping enterprise. On Hashima the tunnels and chambers carved out of the rock

ๆ Corresponding author. 
were matched by the flattening of the site with slag waste and the erection of Japan's (then) largest concrete building in 1916, along with, later, a nursery and school, shops, restaurants, a cinema, a hospital, a gymnasium, and roof gardens, all within an encircling sea wall.

The wall, Brian Burke-Gaffney writes, "gave the island the appearance of a battleship riding the waves. The resemblance was so uncanny that a local newspaper reporter dubbed it Gunkanjima (Battleship Island), a nickname that soon replaced the official name in common parlance" (2002; see figure 1). The six-story apartment block "provided cramped but private lodgings for the miners and their families. Each apartment consisted simply of a single, sixtatami-mat room (9.9 square meters) with a window, door, and small vestibule - more like a monk's cell than an apartment ... . Bathing, cooking, and toilet facilities were communal." More apartment complexes were to follow, "until the tiny island bristled with more than 30 concrete buildings" (see figures 2, 3, and 4). For Norihiko Tsuneishi (2011), it is the continuous deflection of the line of sight that marks the ensuing geography as grotesque, as well as its continual transmogrification from reef to slag to concrete. He notes how the architectural historian Akui Yoshitaka,

"expressed the difficulty in identifying the level on which he was standing when working on his land survey on the island. The spatial disorientation was due to the way in which the buildings were erected, jostling each other on the steeply rugged terrain and creating a gloomy labyrinth like space. Consequently, Akui set up the virtual ground level of the island at the roof level of the buildings. This strategy conceptually reconfigured all the levels below the roof as underground space. Hashima thus involves this elevation dialectic: an abyss that is mountain, and towers that are subterranean passages."

This concrete environ became a site of forced labor using Japan's Korean and Chinese colonial subjects between 1939 and 1945: and this period is revisited in Korean author Han Soosan's (2003) novel Khamagui. For the course of the Second World War, certainly, as well as the Korean War, the mine's output was to prove a prime means of production for military as well as industrial growth. In 1959, the island reached a peak population of over 5000; in terms of population density, this would equate to approximately 835 people per hectare. Under the aegis of Mitsubishi, freshwater was piped in from the mainland, food and other supplies were

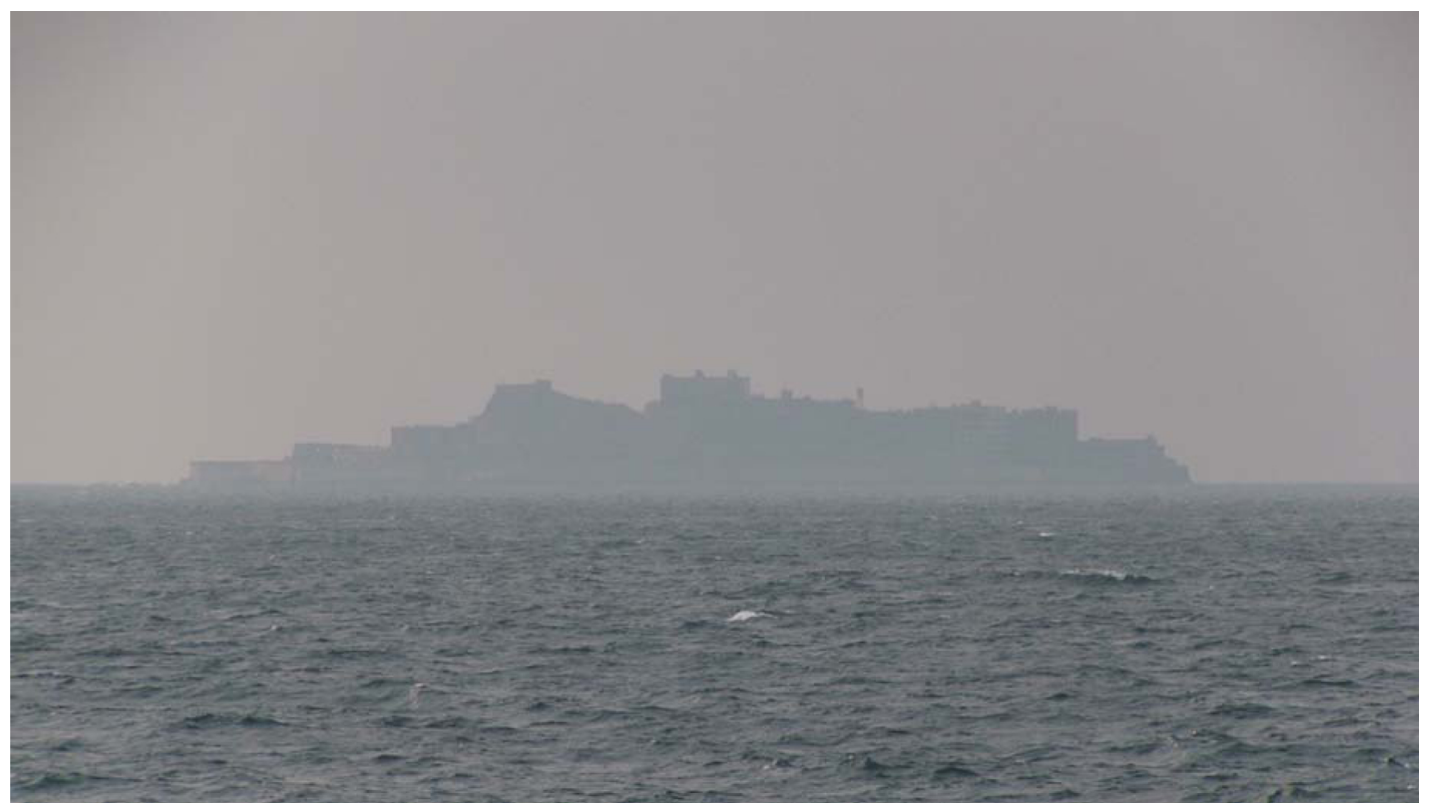

Figure 1. [In color online.] Hashima Island (photograph by Peter Matanle, OPeter Matanle). 


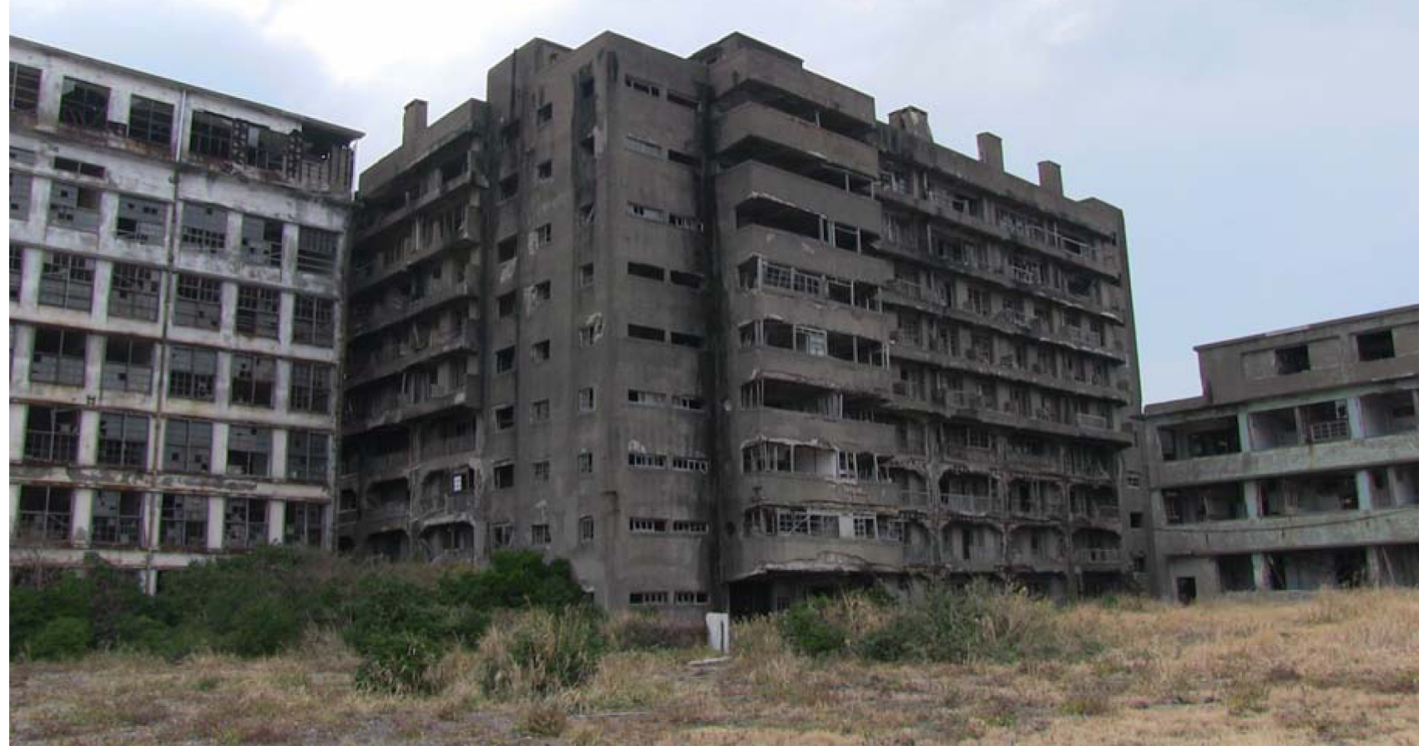

Figure 2. [In color online.] Apartment building (photograph by Peter Matanle, (OPeter Matanle).

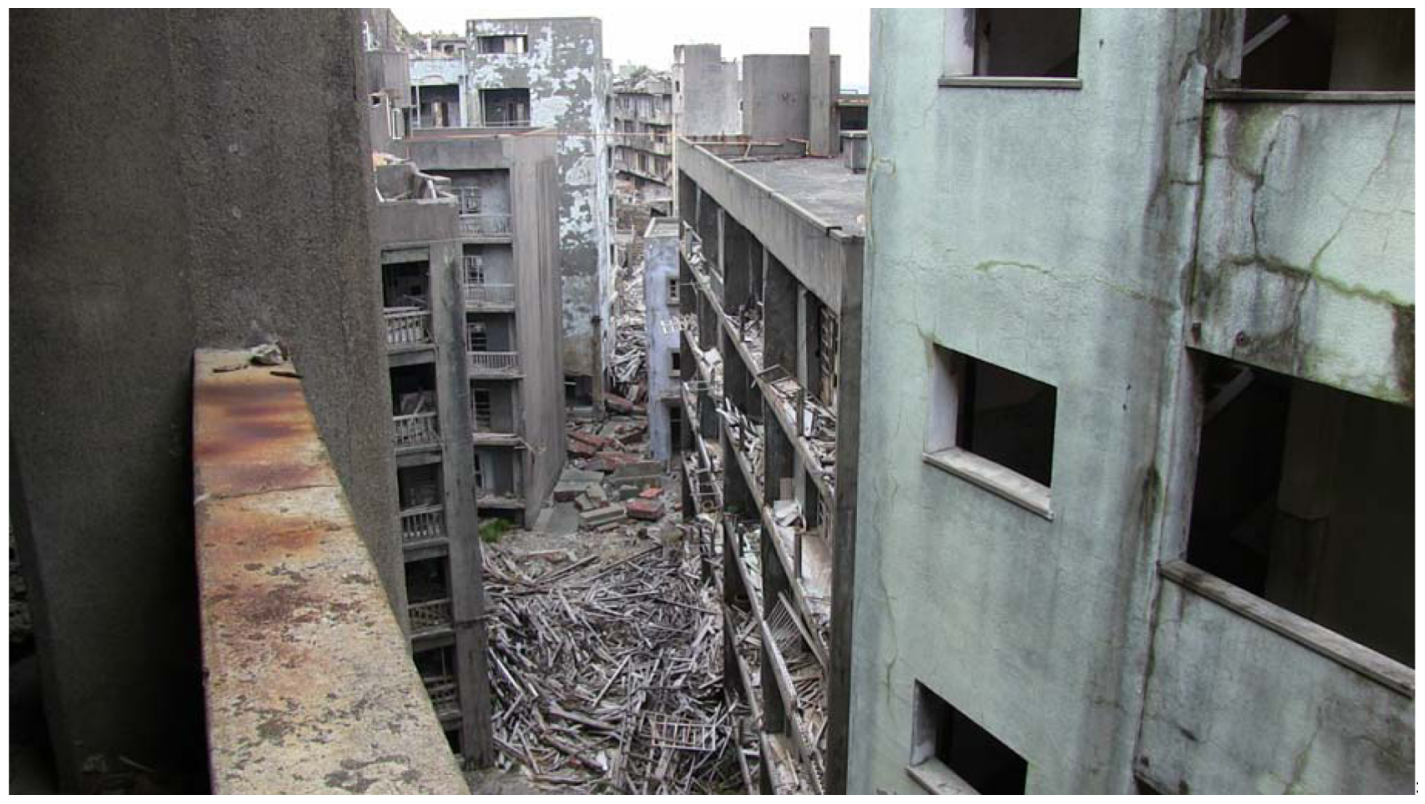

Figure 3. [In color online.] Main Street (photograph by Peter Matanle, OPeter Matanle).

brought in by ship, and residents cleaned and maintained all of the facilities. Quoting an old miner, Burke-Gaffney (2002) writes,

"one could walk between any two points on the island in less time than it took to finish a cigarette. Umbrellas were also unnecessary: a labyrinth of corridors and staircases connected all the apartment blocks and served as the island's highway system."

The one wooden house on the island, perched at the exposed top of the original reef, belonged to the manager of the Mitsubishi Hashima Coal Mine.

As coal gave way to petroleum as a primary source of energy the workforce at Hashima was reduced step by step until the final closure of the mine in 1974. Devoid of residents and exposed to the elements, the site's buildings and their interiors quickly became perilous 


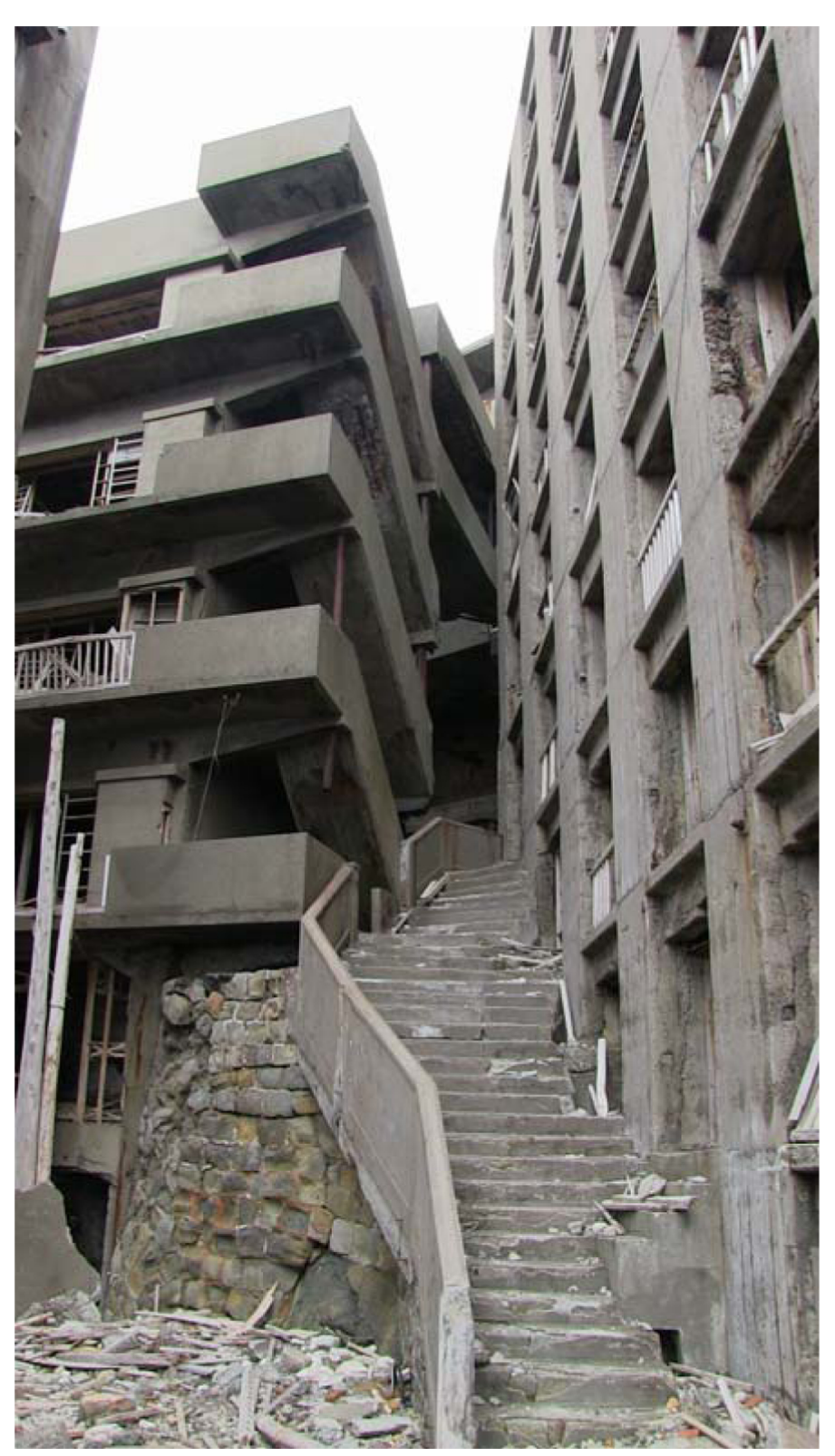

Figure 4. [In color online.] Stairway (photograph by Peter Matanle, OPeter Matanle).

and Hashima was made officially off limits to visitors. Nevertheless, Hashima was to become an 'underground' destination for urban explorers and ruin enthusiasts whose pictures of 'lost' objects shot against a decaying landscape can be found on various social media sites. ${ }^{(1)}$ In 2009 the island once more became accessible to the public as a tourist destination, albeit from the confines of the docking area and a boardwalk, and there are plans by the government to have it designated a UNESCO heritage site. For Burke-Gaffney (2002), Hashima, exploited and emptied, is a concrete mass of constellations and significations; Hashima offers,

"'a view of the end result of 'development,' the fate of a community severed from Mother Earth and engaged in a way of life disconnected from its food supply. In short, Hashima is what the world will be like when we finish urbanizing and exploiting it: a ghost planet spinning through space—silent, naked, and useless."

${ }^{(1)}$ See, for example, the essay and photo montage Gunkanjima: Ruins of a Forbidden Island at http:// gakuran.com/gunkanjima-ruins-of-a-forbidden-island/ 
The strange, uncanny feel to the island has appealed to photographers, filmmakers, and artists; here, images evoke a sense of loss of the past, as well as a sense of dread for the future, both materialized in the flesh as a visceral shudder. It features in Thomas Nordanstad and C M von Hausswolff's (2002) documentary HASHIMA, Japan, in which they accompany a former resident back to his family's apartment and his schoolroom. The island, they find, "was left as if a neutron bomb had gone through it, with people's breakfasts remaining on the tables, bicycles leaning on the walls, and beds still unmade. It is a harrowing place." (2) It reappears in Ben Rivers's 'science fiction film' Slow Action (2011), which seeks to document postapocalyptic, island ecosystems configured by isolation, loss, and abandonment; these invoke a "conception of the Earth in a few hundred years; the sea level rising to absurd heights, creating hyperbolic utopias that appear as possible future mini-societies." (3) External shots of Hashima even help form the backdrop to scenes of the villain's lair in the recent James Bond movie Skyfall (2012): ${ }^{(4)}$ so uninviting are the "crumbling grey structures" of Hashima, writes engineering journalist Jason Goodyer, with its "large sea defences and intimidating militaryesque silhouette", that "it's just the sort of place where an uber-villain might want to situate their hideout. ... All that remains of the many residential buildings are vast skeletal remains that somewhat poignantly recall the devastation wrecked by the US military's Fat Man when he was unleashed on Nagasaki, the island's closest mainland city."(5)

\section{A sk[e]in of indissoluble antagonisms}

How to write in response to such a monstrous geography? What style to adopt for an islandHashima - masticated, poisoned, in ruins? The answer, perhaps, at least the one that made most sense to us, was to mine the baroque as a means of grasping and articulating the island's materialities, and the spatiotemporalities they express. The baroque that we are interested in, however, is not the baroque of Gilles Deleuze (1992), the baroque of the fold, the ecstatic, joyful, and generative play of curves, veils, and pleats. Rather, we are drawn to the dark or saturnine baroque expressed by Walter Benjamin in The Origin of German Tragic Drama, his 'failed' Habilitationsschrift, which was published posthumously in 1963 (Benjamin, 2003 [1963]).

According to Benjamin, baroque tragedy has little in common with classical tragedy forged through myth, suffering, and transcendence, and populated by heroes already silenced and deadened by prehistoric laws. On the contrary, baroque tragedy is best described as a Trauerspiel or mourning play, a work characterized by melancholy and black bile: "The basis of its existence is revealed in the fata morgana of a realm of absolute, that is to say godless, spirituality, bound to the material as its counterpart, such as can only be experienced through evil", he writes. "Its dominant mood is that of mourning ... [in] the bottomless bit of contemplation" (Benjamin, 2003, pages 230-231). This is a tragedy thoroughly concerned with the linearity of time, the struggle for moral autonomy, and the realpolitik of domination. And yet, the rulers of a world now devoid of metaphysics, whose very existence is predicated on the need to decision-make in the face of emergency, stumble, and fall; paradoxically, they find themselves turning to natural history as a means of grounding their absolute authority. "Trauerspiel monarchs", writes Lisa Koepnick, "depend on political spectacles that collapse history into nature, render the speeches of morality silent again, transform the body into a marionette, and thus reinvoke mythic residues to stabilize the fragile lines of political hierarchy in a disenchanted, differentiated society" (1996, page 280). Such spectacles - the theatrics of power-disorientate the senses of their audience, as well as their reason.

\footnotetext{
(2) From http://www.nordanstad.com/videos/hashima-japan-2002-documentary-version/

${ }^{(3)}$ From http://www.benrivers.com/slow.html

${ }^{(4)}$ Directed by Sam Hender (Eon Productions).

${ }^{(5)}$ From http://eandt.theiet.org/magazine/2012/10/hashima-island.cfm
} 
In Benjamin's reading, baroque tragedy appears in Europe towards the end of the 16th and middle of the 17th century as a Catholic response to the Protestant Reformation. In Spain, in the work of Pedro Calderón de la Barca, baroque theatre is affirmative and selfreflexive, rooted in the idea of the theatrum mundi (that is, all the world is a stage ruled by one great director). By contrast, in Germany, in the upheavals caused by the Thirty Years War and in the hands of Lutheran playwrights, deprived of any redemption through good works, "something new arose: an empty world" (page 139). As Benjamin presents it, the German Trauerspiel is characterized by an intense concern with history: in particular, the machinations of court life, such that, "the image of ... the court becomes the key to historical understanding" (page 92). But in this courtly life, as in Shakespeare's Hamlet, which for Benjamin is an early precursor to the mourning play, there is nothing to admire or pity about the protagonists. All is machination and mask. Baroque tragedy has little truck with heroes; its stock characters are tyrants, cynical despots, vacillators, intriguers; the atmosphere is thick with violence, degradation, and evil. In the mourning play, landscapes are both petrified and blasted. Everyone - everything — is guilty, abandoned, "mirrored in the swamp of Adam's guilt" (page 129). In this forlorn, Godless world, Benjamin states that time has been superseded by space; here, "In contrast to the spasmodic chronological progression of tragedy, the Trauerspiel takes place in spatial continuum" (page 95). More specifically, Benjamin suggests that in German baroque tragedy, "history merges into the setting ... like seeds scattered over the ground" (page 92). Here we find two defining topoi of the baroque: explicitly, the ruin and, implicitly, the labyrinth.

For us, Benjamin's comments on the German baroque are thought provoking. We are taken with the play of time and space in the baroque, such that there is no redemption through history, no telos, no end to suffering. What remains is an accumulation of destruction and failure splayed not so much over as through the landscape, "a sorrowful dispersal" (page 186). And, we are struck by the particular manner in which distinctions between nature and culture, a human and a natural history, are negotiated, such that, "In nature [the playwrights and poets] saw eternal transience, and here alone did the saturnine vision of this generation recognize history. ... In the process of decay, and it all alone, the events of history shrivel up and become absorbed in the setting" (page 179). Here, human beings have no specially divine light, no purpose. Rather, like everything else in nature, creatures amongst other creatures, they are subject to decline and decay. This explains the logic inherent in one of the most famous passages in The Origin of German Tragic Drama; that is, the moment when Benjamin contrasts the transcendent joy of Romantic symbolism with the allegorical melancholy of the baroque:

"Whereas in the symbol destruction is idealized and the transfigured face of nature is fleetingly revealed in the light of redemption, in allegory the observer is confronted with the facies hippocratica of history as a petrified, primordial landscape. Everything about history that, from the very beginning, has been untimely, sorrowful, unsuccessful, is expressed in a face - or rather in a death's head ... . This is the form in which man's subjection to nature is most obvious" (page 166).

Baroque tragedy's sadness, its collapse of history into natural history, accounts for its attraction towards ruins, which Benjamin defines as "the perfect vision of the new phenomenon", such that,

"That which lies here in ruins, the highly significant fragment, the remnant, is, in fact, the finest material in baroque creation. For it is common practice in the literature of the baroque to pile up fragments ceaselessly, without any strict idea of a goal, and, in the unremitting expectation of a miracle, to take the repetition of stereotypes for a process of intensification" (page 178). 
In Benjamin's view, the ruin is not merely a setting or background for action; it is both a principle of composition and mode of interpretation rooted in an allegorical sensibility. Benjamin is attracted to allegory for the way in which it avoids immediacy - the illusion of presence - by drawing attention to its own signifying structure. Like a ruin, then, allegory is an essentially blasted form. By showing that ' $\mathrm{X}$ ' is not ' $\mathrm{X}$ ' but a sign for something else, allegory does not thus privilege this something else as somehow more profound or truthful. Rather, it highlights the abyss, discloses the void, and, in the process, reveals history to be a pure construct, a matter of invention and convention.

In the hands of the gloomy German baroque playwrights of the 17th century, the shifting terrain of allegory became a way for admitting transience, while, at the same time, holding out the possibility of an escape from history. Crucially, this dialectic of hope does not come from human striving or will; rather, it is granted from without, through grace, through the "wide arc' of redemption, "the about-turn" (page 232). For Scott Lash, writing on the politics appropriate to a posthuman epoch, Benjamin's melancholic is a precocious harbinger for the extruded, ab-jected outcasts who mourn for past objects, disused things, the ruins of the city; they are the inventors as well as the preservers of tradition in an age of indifference (1998, page 317). For Alan Latham, the habitually grounded mode of perception that lies at the heart of Benjamin's critique of city life under modernity is used to describe an experiential entropy, to be sure, and a lack of critical distance; but there is also an ethics of sensuous encounter here, he argues, that can itself provide insight into the "self's capacity for meeting the world within structures of mutuality" (1999, page 453).

If the ruin posits the baroque as a type of melancholic fragmentation, a saturnine encounter with blasted architectures, then the labyrinth, which appears so obsessively in Benjamin's later writings, yet endows the experience of the baroque with a glimmering of myth. Although Benjamin does not engage with the topos of labyrinth in The Origin of German Tragic Drama per se, his later writings on cities, in particular Berlin, Moscow, and Paris, suggest that the labyrinth qua city takes the place of the Baroque stage, albeit as a form of memory work. Susan Sontag underlines this shift in figuration in her preface to One Way Street (Benjamin, 1985). According to Sontag, "in 'Berlin Childhood' and 'the Berlin Chronicle', Benjamin merges his life into a setting. The successor to the Baroque stage set is the Surrealist City: the metaphysical landscape in whose dreamlike spaces people have a brief, shadowy existence" (1985, page 13). Leaving aside the relationship that Sontag posits between the baroque stage-set and the surrealist city, the important point to grasp here is that the labyrinth becomes an additional, oblique trope for the baroque - what we might call a figural elaboration - even though Benjamin does not adumbrate this connection in any direct or frontal way.

For Benjamin, the labyrinth is a dream space where ruins aggregate and accumulate, and where contemporary baroque heroes (the rag picker, the prostitute, the gambler, the flâneur) are able to wander endlessly through a phantasmagoria of buried memories, forgotten histories, old fears: thus, street, he writes,

"must be profiled against the older term 'way.' With respect to their mythological natures, the two words are entirely distinct. The way brings with it the terrors of wandering, some reverberation of which must have struck the leaders of nomadic tribes ... . The synthesis of these twin terrors, however - monotonous wandering - is represented in the labyrinth" (2002, page 519).

In Benjaminian thought, to enter the labyrinth is to enter a realm where the real and mythological overlap, interact, become porous. In the evocative labyrinth of Parisian street names and metro stations, Benjamin tells us that Theseus still seeks the Minotaur, that Orpheus continues to look back at Eurycides, and that Hades awaits: "names in the city ... become potent when they issue within the labyrinthine halls of the Métro. 
Troglodytic kingdoms - thus they hover on the horizon: Solférino, Italie, Rome, Concorde, Nation. Difficult to believe that up above they all run into one another, that under the open sky it all draws together. Antiquity" (Benjamin, 2002, page 519). To see the city as labyrinth, then, is to reject any sense of history as linear movement, and to affirm, rather, the contiguity of antiquity and modernity, the irrational and the real, the human and the animal. This collapse of categories not only shatters Enlightenment ideas of progress by positing the city - perhaps any social space - as a repository of failed histories and broken trajectories; it uses mythology as a strategy for deconstructing the dominant but hidden myths of contemporary capitalism. As Graeme Gilloch points out, the labyrinth is part of Benjamin's tactical repertoire, part of his panoply of “ 'dialectical fairytales' which seek to disenchant the modern city through enchantment" (1997, page 85). In the enchanted spaces of the labyrinth, modernity gives up its ghosts, tears off its mask, strips away its fetish to reveal the abjected and hidden face of the monster, that hunchback, that Minotaur which Benjamin sought to love, seeing in it the potential for redemption through base materiality.

Although our project on Hashima owes little to the messianic gnosticism of Benjamin, or his Carl-Schmitt-infused take on politics as decision making, ${ }^{(6)}$ his comments on the baroque, seen through the lens of the Weimar, with its obsession with ruins, nature, and petrification, and the ruin that is allegory, is an inspiration for our own attempt at writing in response to Hashima. Like the baroque playwrights he cites in The Origin of German Tragic Drama, we too are concerned with dialectics, reversals, and history as setting. We do not so much peer into an abyss, however, as taste the monstrous taint of an island sped up and spat out. In the following allegorical tale, our aim is to create a jumbled temporality in which the ruined buildings of Hashima Island point backwards and forwards in the same restless motion. If, in our text, it becomes impossible to separate history from natural history, the story we want to tell is one in which ruins point towards the future, and where hope is found in melancholy. As the reader will soon discover, our comrade Hassall's greatness, his monstrosity, resides in his capacity to affirm the baroque, which is why, no doubt, he decided to forsake the clean and proper illusions of the mainland, and stay on the island in the hope of remaining close to the very source of evil and discomfort. In this embrace of a blasted, toxic nature, Hassall transformed himself into a baroque hero, a modern-day Theseus whose heroism resides not in his decision to kill the Minotaur and to leave the labyrinthine ruins of Hashima, but rather in his desire to remain in the labyrinth and to become Minotaur. Ultimately, though, it is impossible to tell if Hassall's affirmation of the monster was for his own cynical ends or for the benefit of the island itself; which, given the nature of baroque allegory, characterized, as it is, by unresolved ambivalence and dialectical tension, is exactly as it should be.

\section{Writing from the labyrinth: Carl's story}

It started, as ominous things often start, on the first day of the year. On New Year's Day 2012, Deborah contacted me asking if I'd be interested in collaborating with her on a project about monsters. Knowing little about the topic, I immediately said 'yes'. Strangely, Deborah made no mention of Hashima until a week or so later when, in a moment of profound inspiration, she sent a weblink directing me to that place, that isle of ruins, which was to have such shattering implications for my life, penetrating, as it still does, my consciousness, colonizing

${ }^{(6)}$ As Christine Buci-Glucksmann puts it, "we find in Benjamin's articles of the twenties on violence the same continual passing between Jewish messianism, centred on the idea of catastrophic rupture, and a 'metaphysical,' anti-state anarchism close to Sorel, with an incipient train of thought which borrowed from Carl Schmitt's early analysis of the political as 'sovereignty that decides in state of emergency.' This vocabulary impregnated The Origin of German Tragic Drama, as it would much later the "Theses on the Philosophy of History"' (1994, page 64). 
even my dreams. It was hard to say if I have been affected or infected. At any rate, the results are the same.

The more I reflect on it, the more impossible it becomes to distinguish my feelings about Hashima from my feelings about Hassall, both of whom will be always and forever linked in my mind. And as I write this, I notice, for the first time, the subterranean connection enmeshing those two examples of baroque monstrosity in some abject confederacy. Listen again to the sounds of their names, paying particular attention to that most guttural, the oldest of all consonants - the aspirate ' $h$ ', which, as I mould its articulation in my thorax, exists as a murmur come from the deep, amphibian: a sound of humanoid gills. Hashima, Hassall, Horror - an onomatopoeia of disgust. Reptilian, Devonian, Protozoic.

When I first saw those haunting images of Hashima pixellated on my screen, I knew instinctively that Hassall had to be involved. Only he had the necessary tools to map the geography of its distress; no one but him had sufficient cynicism to exist as a baroque hero. I had first met Hassall in the dark days of the 1990s. Depressed by the failure of ecstasy and rave culture to transform the world, Hassall wanted to trade in his humanity: his goal to become nothing, to journey to what he called 'the land of the monster'. I was drawn to the purity of his vision, and to the intensity of his gnosticism. He was - and remains - a committed man.

Together, we read Bataille, watched cows having heart attacks in empty fields, and were mesmerized and depressed by the growth of Morrisons and Weatherspoons. The tragic Spring of the Paris Commune-les temps des cérises - sustained us through those dark days, as did our heroes, the great double acts, the great grotesques: Punch and Judy, Don Quixote and Sancho Panzo, Marx and Lenin, Bouvard and Pecuchet, Flanagan and Allen, and perhaps, most poignantly of all, the Crankies. Hassall found tragedy and sadness everywhere: in the birth of children, in the falling of a leaf, in the appearance of the shell suit on the British high street, and in the terrible masochism of Abba's "Take a Chance on Me" (1977), which he deconstructed daily.

I contacted Hassall in mid-January 2012. His enthusiasm was immense; he wanted to leave immediately; and so on Valentine's Day, after a long journey that included two flights, a train, and a boat trip, we staggered onto the shores of that husk of a place, that island of rot: Hashima.

I hadn't seen Hassall for over a decade, and in that time he had aged terribly. His hair was now lank and lifeless, his body bloated by junk-food and ravaged by a tapeworm. But still in that amorphous, depressing mass of flesh, I could spy the vitality of the man, and, as I looked at him in the grey half-light, I recalled Captain Bligh's description of the mutineer and deserter, Fletcher Christian. Bligh described Christian as: "5 ft. 9 in. high $[175 \mathrm{~cm}]$. blackish or very dark complexion. Hair-Blackish or very dark brown. Make-Strong. A star tatowed [sic] on his left breast, and tatowed [sic] on the backside. His knees stand a little out and he may be called a little bow legged. He is subject to violent perspiration, particularly in his hands, so that he soils anything he handles." (7)

While I slept on the plane, Hassall had been reading about Hashima, doing his homework. He was concerned that it would soon be transformed into a UNESCO heritage site, just another place on the dark tourist circuit, a postmodern necropolis from which all history - that is to say, all barbarism - would be evacuated, covered over, whitewashed. Hassall excoriated the artist Ben Rivers who had used Hashima as a backdrop for his apocalyptic sci-film Slow Action. He was anxious, too, about a rumour he'd heard from an ex-lover in the Hollywood Hills, now become studio executive, who told him that Hashima was to feature in the next James Bond movie Skyfall. ${ }^{(8)}$ Hassall was furious at the prospect, apoplectic with rage.

(7) From the Bounty's Crew Encyclopaedia, maintained by the Pitcairn Islands Study Centre, at http:// library.puc.edu/pitcairn/bounty/crew.shtml

${ }^{(8)}$ Hassall's information was correct. Skyfall was released to great fanfare in 2012. 
He broke into a long critique about fascism, architecture and nostalgia, talking about Albert Speer's plan to design a building with a ruin in it.

"Speer wanted to build structures that would decay gloriously, impressively, like Roman ruins. No rusty hulks or gnarled steel slums. He knew that Hitler would be in favor of anything that might astonish posterity. He did a drawing of a Reich structure that was to be built of special materials, allowing it to crumble romantically - a drawing of fallen walls, half columns furled in wisteria. The ruin is built into the creation, which shows a certain nostalgia behind the power principle, or a tendency to organize the longings of future generation.

I don't trust anybody's nostalgia but my own. Nostalgia is a product of dissatisfaction and rage. It's a settling of grievances between the present and the past. The more powerful the nostalgia, the closer you come to violence. War is the form nostalgia takes when men are hard-pressed to say something good about their country." (9)

Then, sniffing the air for inspiration like a dog on heat, Hassall, eyes closed, solemn as a judge, came up with the idea, the concept that would allow Hashima to retain its monstrosityhe suggested that we engage in a series of dialectic exorcisms, conjuring in reverse. I was lost, floundering in Hassall's brilliant intellectual slipstream, and had, hesitantly, to ask what he meant. What exactly was a dialectic exorcism? As usual, Hassall proceeded using the Socratean method:

Hassall: Look around you, Carl. What do you see?

Carl: I see devastation, destruction, fragments of things, matter out of place-dust, children's toys, broken shoes, bent plastic, a gossamer haze.

Hassall: What does it you remind of?

Carl: The ecotoplasm of a ghost - it's like some mad ecocide has taken place here, a kind of Jonestown massacre, but inflicted, this time, on nature itself. The violence is overwhelming. The island seems to contain it, even to reflect it back-it's as if the sea, the wind, the sky on Hashima are whispering to me, communicating some terrible act. I can feel it in the silence.

Hassall: What do you normally do with ghosts?

Carl: $\quad$ Exorcise them.

Hassall: So let's stay with this, Carl. If an exorcism rids us of monsters, then a dialectical exorcism aims to reverse the process. You might say that it seeks to deify the monstrous, to make it visible, to give it consistency. That's what we're going to do, Carl, make Hashima irrecuperable, to save its horror. I've been studying chaos theory, grappling with the complexities of quantum physics. If every gesture we make shifts all the atoms in the Solar System, then a sufficiently intense or insane gesture - a dialectical exorcism, I would make so bold - might be strong enough to materialize the monster, to make all the atoms in the universe ricochet into each other, and pile up in an aggregate. It's my contention, my wager, that such an aggregate could withstand anything, even a tsunami.

I looked then, as I'd always looked at Hassall, with a sense of awe and terror. Let there be no mistake. There was a grandeur to his baroque madness; he seemed to commune with the universe, channeling its power. His shadow suddenly became immense, and he loomed over me, standing higher even than the abandoned tower blocks of Hashima that stood there rotting in the heat of the tropical sun. With what seemed to be a smirk, a sign of his usual

${ }^{(9)}$ Typically, Hassall's words are plagiaristic. He appears to have 'borrowed' them from the US novelist Don DeLillo's environmental satire White Noise (1985). 
reckless confidence, Hassall laid out his dramaturgy for the project. There were to be three stages to it:

- First, we were to dress as plague doctors.

- Second, we were to intone the opening stanza of Milton's Paradise Lost (1667) in an attempt to divine its incantatory force, to tap its righteous anger.

- Third, we write postcards from Hashima, summoning the dead, conjuring monsters. Hassall, as only he could, saw the postcards as lamentations, as 'prayers', as examples of threnody. Hassall, for his sins, had been teaching Performance Studies in some minor university in the West Midlands. He hated it, of course, castigating staff and students alike for their cowardice, their reluctance to follow him on his whirlwind of monstrosity. Buoyed by the possibility of what he called 'untethered freedom' - and what we would simply call 'chaos' he was eager to test out his pedagogy on the desolate putrefaction of Hashima, which lay before us like a prolapsed bowel. Small eruptions of methane gas surfaced from the old underground mines and erupted through the cracks in the distressed concrete that covered the island, hanging in the evening air as thick clouds of toxic substance. White on grey.

In that atmosphere of thickening gloom, Hassall suggested that we make preparations for the exorcism by mapping the island, using a pentangle to construct a cartography of its horror. He saw us, or so he said to me, as surveyors, topologists. When I mentioned Franz Kafka's use of the surveyor figure in The Castle (1926), Hassall sneered, hissing that he had no truck with Kafka's guilt, and mocking me for being too banal, too bourgeois, too obvious. I had wanted then to scuttle away, to hide under a rock, to become lizard.

Hassall explained that we had to be strong to withstand the consciousness of Hashima, to resist toppling into the force field of its battle-shaped mind. Kafka's delicate sensibility was no use here. At that very moment, a huge wave broke on the sea wall, and showered us in black soot. The sea was poisoned, like the land on which we stood.

Hassall continued his discourse, arguing that to withstand horror, to live in the land of the monster, we had to be infected by it, allow it to 'touch us,' to penetrate our skin as in some mad act of homeopathy. Although I said nothing to him for fear of rebuke, I thought of the opening paragraph of Elias Canetti's Crowds and Power:

"There is nothing that man fears more than the touch of the unknown. He wants to see what is reaching towards him, and to be able to recognise or at least to classify it. Man always tends to avoid contact with anything strange. In the dark, the fear of an unexpected touch can amount to panic. Even clothes give insufficient security: it is easy to tear them and pierce through to the naked flesh of the victim" (1962, page 15).

With Canetti in my mind, I gazed into the center of that hell-pit called Hashima, menaced by the constant circling and squawking of blackened kites, those terrible creatures. There were stories of kites and tadpoles living off plastic, drinking effluent, and transfiguring themselves into synthetic monsters with iron beaks and unbreakable polyester tails.

Hassall read out witness reports. He told me of the zoo in the center of the island, occupied by monkeys, elephants and lions, and squeezed into 5 square meters of territory. The miners who lived in Hashima would feed the monkeys cigarettes and laugh as they spat up their blackened lungs onto the smooth concrete walls of their prison. Horror on horror. What did they hope to achieve? To enter Hashima was to enter a fold of violence, the island a labyrinth of degradation.

As we strode through the ruins of Hashima, through the tower blocks, through the empty cinema, through abandoned schoolrooms with colonial maps and stopped clocks on their walls, through the empty playgrounds of rusted equipment, I felt at times like an astronaut, abandoned forever on some strange planet, while, at others, I imagined myself a sailor on one of Captain Cook's clipper ships high on opium and coming face to face with the savage statues of Easter Island, abandoned under an immense sky. 
At the very apex of the pentangle, at the entrance to what the residents of Hashima called 'hell's staircase', Hassall stopped and read out a testimony from one of the South Korean prisoners of war, who were made to work on the island during World War II:

"I was one of two boys forced onto a truck in my village and taken to the government office, where several thousand other Koreans ranging in age from about fourteen to twenty had been gathered. After a night at an inn, we were taken by truck to a nearby city, then by train to the port at Pusan and ship from Pusan to Shimonoseki. About 300 members of the group, including myself, were then taken by train to Nagasaki, where we arrived the following morning. All of us were being sent to Hashima.

I had relatives in Japan, not only my parents in Nagoya but also family members living in Sasebo. I thought that no matter where I was sent in Japan I would be able to escape and find shelter with them. But as soon as I saw Hashima I lost all hope.

The island was surrounded by high concrete walls, and there was ocean, nothing but ocean, all around. It was crowded with concrete buildings as high as nine stories ... . We Koreans were lodged in buildings on the edge of the island. Seven or eight of us were put together in a tiny room, giving each person no more than a few feet of space.

The buildings were made of reinforced concrete and had mortar on the outside, but the interior was filthy and falling apart... . We were given uniforms like rice bags to wear and forced to begin work the morning after arrival. We were constantly watched and ordered around by Japanese guards, some of whom were wearing swords.

The mine was deep under the sea, the workers reaching it by elevator down a long narrow shaft. The coal was carried out from a spacious underground chamber, but the digging places were so small that we had to crouch down to work. It was excruciating, exhausting labor. Gas collected in the tunnels, and the rock ceilings and walls threatened to collapse at any minute. I was convinced that I would never leave the island alive." (10)

With those words of devastation ringing in our ears, and soaked to the skin with the acid rain that fell on the island, Hassall suggested we inscribe an incantation, which he called, somewhat pretentiously I thought, "scores for performance". Hassall's intent was to allow the island to penetrate through our senses, to touch us through the eyes, nose, skin, and ears, which, after Antonin Artaud, he called "the holes in the head nearest to consciousness". This is my entry for eyes:

On Hashima, with these eyes I saw: a world in chaos, a great churning belly of a thing, a bowel, a city of rust and coal dust:

- twisted plastic

- red corrosion

- yellow stains

- soiled mattresses - striped

- beer bottles

- a crèche

- blue rubber gloves

- a jar of Nescafe

- cat shit

- bat shit

- a figurine of the Eiffel tower

- a blackboard

- children's crayons scattered

- a packet of condoms

- distressed pipes

${ }^{(10)}$ Cited by Burke-Gaffney, at http://www.cabinetmagazine.org/issues/7/hashima.php 
- rotting timber

- huge bloated books

- white spume

- lonely tools

- chisels

- spanners

- hammers

- ratchets

- broken glass

- thick pools of oil

- slides

- trampolines

- the lost arms of a Barbie doll

- the torso of a Ken

- gutted radios

- mildewed paint

- crumbling chairs

- entropic leather

- turbidity

- toxic drift

- lesions

- afflicted matter

- a dark star

- a black prayer

- an oxidized Buddha

- a Zen garden

No proper objects, just fragments of anguish. All dimensions imploded, like a field of intestines. It takes courage to venture out but even more to stay in. There is precious little to distinguish one thing from the other, the unthinkable is materialized here: the terrible mystery, the monstrosity, an ontology of horror. Hideous. As if one were living without horizon in the dust of a dead planet.

Hassall encouraged us to write postcards, missives of various lengths, to people, places, things. There was to be no order, just vitriol. He intended to use these for the second stage of the performance, and to juxtapose them with lines from Paradise Lost in some mad baroque poem. Some of the recipients were: Hieronymus Bosch, Francisco Goya, Pieter Brueghel, Paul Gascoigne, Heiner Muller, Marx and Engels, Jean Genet, Leonard Cohen, Monica Vitti, Neil Armstrong, the Chuckle Brothers, David Walliams, Dow Corning, Werner Von Braun, Italo Calvino, the Women's Institute of Malvern, The Museum of Lost Objects, Antonin Artaud, Basho, the victims of Nagasaki, Samuel Beckett, Matthew Gandy, Samuel Palmer, William Burroughs, David Pinder, Oliver Cromwell, Walter Benjamin, Caroline Spelman, John Berger, and the mysterious missing chin of Michael Gove.

Despite my attempts to persuade him, Hassall refused to let me engage in the lamentations from Milton. He was determined to remain on the island, seduced by its geometry of ruins and labyrinthine halls. He didn't want to return. Drawing on his knowledge of Benjamin, Hassall stood open mouthed, waiting, hoping. In that abject stance, within a site of ruins, he was ready to wager on some kind of difference. He had become obsessed with the notion of dedifferentiation, the idea that mind is matter, a sediment, like a river bank open to erosion. As if his way out of history, his way into the new, was to transform himself into a ruin. As I walked toward the red and yellow fishing boat we had rented for 8000 yen per day, clutching our one remaining roll of film, the last image registered on my retina was of Hassall trying 


\section{Postcards from Hassall}

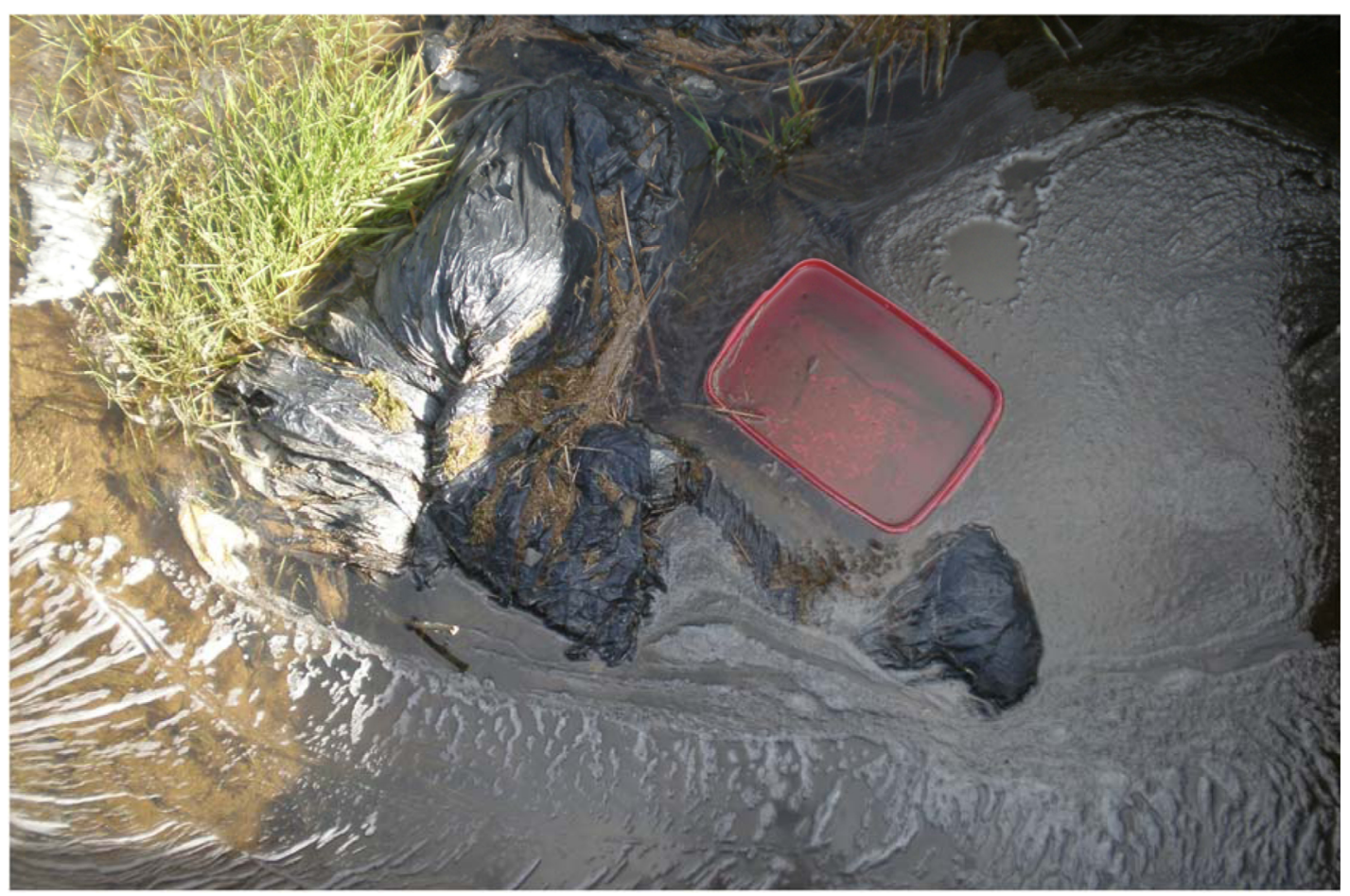

Figure 5. [In color online.] Hashima postcard 23 front and back.

Dear Monica,

I am on Hashima, the gunship island, off the coast of Nagasaki in Southern Japan. The island is quite simply a labyrinth of ruins. No tree grows here; no bird sings; no child plays - all is silent, lifeless, an abandoned future made present.

I was wandering through that site of dereliction and disrepair on a wet Sunday in February 2012, passing through the narrow corridors that shield you from the briny rain, when I came across a battered poster from your 1964 film Red Desert, hidden away, subtitled in Japanese, in a rusty drawer in a now dilapidated cinema - a cinema that is crumbling around my feet.

If images were, for the miners of Hashima, a type of comfort, an anesthetic in colour, what, I wonder, did they make of your performance in Red Desert, filmed by your lover Michelangelo Antonioni in the desolate landscape of the Northern Italian seaport of Ravenna?

Did the miners, I wonder, turn in distress from the pictures projected on that strip of imported celluloid running in front of their eyes in that house of images??

Yours in hope

Hassall 


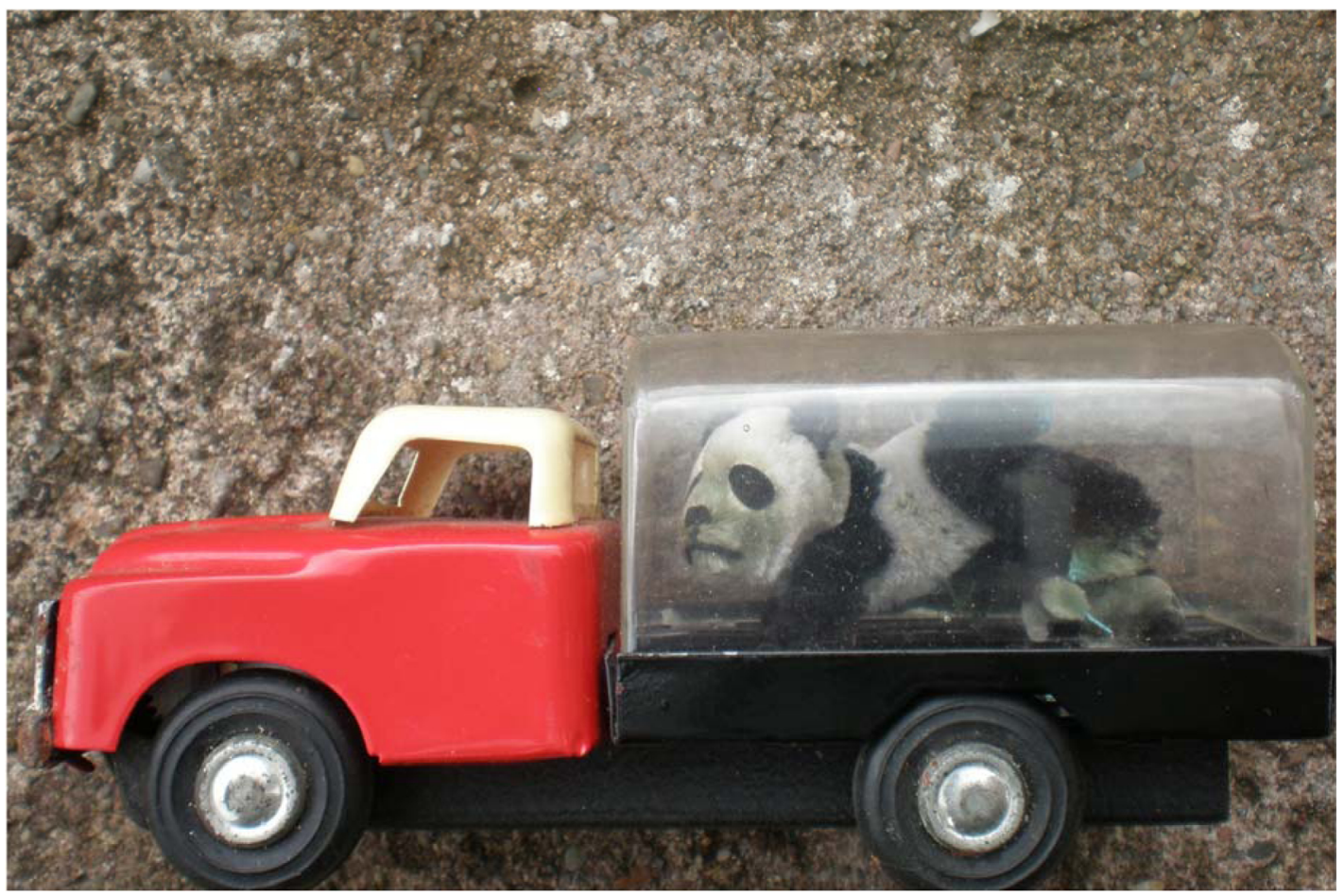

Figure 6. [In color online.] Hashima postcard 24 front and back.

Dear Deborah and JP,

What happens to the city when Hashima seems to exist as its endgame, to foreclose its future, so to speak? The monstrous city is an obscene city, a city that should have remained off-stage, in the wings, behind the curtain. In a hesitant attempt to address the remit of your special issue, I would suggest that to write a baroque geography of the monstrous city is to make the invisible visible, to shift the terrain of theatre, dredging its depths for some dark secret. On Hashima, the dark secret - the secret that should have remained occulted like the face of some lost planet turned away from its sun - is that of a metabolism gone wrong.

I seek to caution you against the future. In the future, I see the monstrosity of Hashima cheapened, a kind of urbanised heroin chic. I want to abandon the future for the infinity of the present, which, for me, is embodied, increasingly, in the proliferating chaos of Hashima, this holocaust of matter. I'm on the lookout for an alternative 'now,' for a different type of performance, for a new relationship to monstrosity.

When they abandoned Hashima in 1974, they said it was like the retreat from Saigon. Which leads me to my final question: how do we retreat from the future?

Wishing you were here

Hassall 
to sink into the labyrinth of Hashima, in a desperate but joyous attempt to become what he always already was: a monster of the baroque, a broken angel.

Acknowledgements. We would like to thank the AHRC 'Care for the Future: Thinking Forward Through the Past' theme for funding the next stage of this research, 'Future of Ruins: Reclaiming Abandonment and Toxicity on Hashima Island' (AH/K005308/1). We would also like to thank Professor Brian Burke-Gaffney, Dr Carina Fearnley, and Dr Mark Pendelton for sharing expertise; Dr Debra Shaw, Anna Wilson, and Charlie Allwood for inviting us to present two keynotes versions of this paper at the University of East London and Queen Mary University, respectively; and finally, the reviewers for their insights and suggestions.

\section{References}

Benjamin W, 1985 One Way Street and Other Writings (Verso, London)

Benjamin W, 2002 The Arcades Project (Harvard University Press, Cambridge, MA)

Benjamin W, 2003 [1963] The Origin of German Tragic Drama translated by J Osborne

(Verso, London)

Buci-Glucksmann C, 1994 Baroque Reason: The Aesthetics of Modernity (Sage, London)

Burke-Gaffney B, 2002, "Hashima: the ghost island" Cabinet 7,

http://www.cabinetmagazine.org/issues/7/hashima.php

Canetti E, 1992 Crowds and Power (Penguin, London)

Deleuze G, 1992 Fold: Leibniz and the Baroque (University of Minnesota Press, Minneapolis, MN)

DeLillo D, 1985 White Noise (Penguin, New York)

Gilloch G, 1997 Myth and Metropolis: Walter Benjamin and the City (Polity Press, Cambridge)

Koepnick L P, 1996, "The spectacle, the 'Trauerspiel,' and the politics of resolution: Benjamin reading the Baroque reading Weimar" Critical Inquiry 22 268-291

Lash S, 1998, "Being after time: towards a politics of melancholy" Journal for Cultural Research 2(2-3) 305-319

Latham A, 1999, "The power of distraction: distraction, tactility, and habit in the work of Walter Benjamin" Environment and Planning D: Society and Space 17 451-474

Sontag S, 1985, "Introduction", in One Way Street and other Writings Ed. W Benjamin (Verso, London) pp 7-28

Soosan H, 2003 Khamagui; republished in Japanese in 2010 as Gunkanjima (Sakuhin-sha, Tokyo)

Tsuneishi N, 2011, "Specters of capitalism: ghostly labor and the topography of ruin in post-industrial Japan", paper presented at the 9th Global Conference on Monsters and Monstrousness, Oxford, September, http://www.inter-disciplinary.net/wp-content/uploads/2011/08/tsuneishimpaper.pdf 